\title{
A STANDARDIZED MODIFICATION OF THE LAUGHLEN TEST FOR SYPHILIS
}

\author{
BY \\ JOHN S. STEVENSON \\ From the Central Public Health Laboratory, Glasgow
}

(RECEIVED FOR PUBLICATION, DECEMBER, 1947)

Laughlen published the first account of his test for syphilis in 1935.

The antigen was made thus: to $1 \mathrm{ml}$. of Kahn antigen was added a "small quantity" of a fat stain (Scharlach R or Sudan III) and four drops of tinct. benzoini co., B.P. The mixture was warmed in a water-bath at $50^{\circ} \mathrm{C}$., and $10 \mathrm{ml}$. of 1.5 per cent saline, also warmed to $50^{\circ} \mathrm{C}$., was added. This pink, milkylooking fluid was "sensitized" by the addition of varying amounts of 9 per cent salt solution. For the test one drop of this sensitized antigen was mixed on a slide with one drop of the serum under examination and gently rocked for 10 minutes; precipitation occurring within this time indiçated a positive result. Several modifications of this technique have been described by various workers.

\section{The Present Study}

The present study was undertaken with a view to finding a simple method of making a reliable Laughlen antigen which was capable of being scientifically reproduced in a standard manner. The components of the antigen were first considered individually.

Kahn antigen.-Experiments with Kahn antigens from several sources showed that the one produced by Burroughs Wellcome and Co. was highly sensitive-it was used in all subsequent work and proved satisfactory.

Stains.-The "knifepointfuls" and "small quantities " referred to in some versions of the Laughlen test are too vague for accurate work. It was found that a simple method of overcoming the difficulty of the very small amount of stain required was to use a 3 per cent alcoholic solution made as follows: to $100 \mathrm{ml}$. of absolute ethyl alcohol in a $250 \mathrm{ml}$. flask is added $3 \mathrm{~g}$. of the stain powder. The flask, stoppered tightly with cotton wool covered with tinfoil, is shaken for 5 minutes in a Kahn "shaker" and placed in an incubator at $37^{\circ} \mathrm{C}$. for 30 minutes. The resulting solution is dark red but contains a thick deposit of insoluble material, which is removed by filtering twice through Whatman's No. 1 paper. The volume is made up to $100 \mathrm{ml}$. with absolute alcohol. By using this solution the stain may now be accurately measured, $0.1 \mathrm{ml}$. being added to $1 \mathrm{ml}$. of $\mathrm{Kahn}$ antigen. This amount of stain solution has no adverse effect on the final Laughlen antigen. Of several fat stains tried, Scharlach $\mathrm{R}$ was found to be the best.

The diluting saline.-Better results were obtained with the Laughlen test when the diluting saline was buffered, with optimum value at $p \mathrm{H}$ 6.6. The buffersaline consists of $9 \mathrm{~g}$. NaCl added to 1 litre of $\mathrm{M} / 15$ Sorensen's phosphates at $p \mathrm{H}$ 6.6. Pyrex glass is used throughout, as a precaution against increasing alkalinity. The figure mentioned above, 0.9 per cent, has been found to be the optimum $\mathrm{NaCl}$ concentration at $p \mathrm{H}$ 6.6. With buffer-saline it is to be noted that alteration of the salt content does not produce the same wide variations in antigen sensitivity as is found with ordinary saline.

The benzoin.-A 1-ml. pipette delivers $0.3 \mathrm{ml}$. (the optimum quantity) tinct. benzoini co. more accurately than "drops."

\section{Preparation of Antigen}

Into a Pyrex test-tube $(6 \mathrm{in} . \times 5 / 8 \mathrm{in}$.) pipette is put $10 \mathrm{ml}$. of buffer-saline. The tube is placed in a waterbath at $50^{\circ} \mathrm{C}$. and left while the other components of the antigen are prepared. To $1 \mathrm{ml}$. of Kahn antigen (Burroughs Wellcome and Co.) in a similar tube is added $0.1 \mathrm{ml}$. of the 3 per cent stain solution and $0.3 \mathrm{ml}$. tinct. benzoini co., and this is placed in the water-bath for 2 minutes. Both tubes are removed and the contents mixed by pouring the saline into the antigen, back and forwards four times. The resulting pink liquid is the modified Laughlen antigen. Sedimentation, which occurs within a few hours, does not impair the qualities of the antigen: before use the colloidal appearance is restored by inverting the container. The sensitivity of the completed antigen is low when first made, but rises to its maximum within the next 30 to 36 hours, thereafter remaining constant for about four months. It should, therefore, be laid aside for about 36 hours before testing. Further sensitization by strong saline is unnecessary. The antigen is stored at room temperature.

\section{The Apparatus}

The mechanical mixer (Plate III a) consists of a circular porcelain plate, marked in 3/4-in. diameter 
circles with black enamel, mounted for rotation at $20^{\circ}$ to the horizontal on an adapted gramophone motor.

Two Dreyer pipettes are needed, one for the antigen and one for sera. They are each calibrated to deliver $0.05 \mathrm{ml}$. serum per drop.

\section{The Test}

The sera are inactivated as usual. The need for inactivation has been questioned by several workers using the Laughlen test, but experience with the present modification has shown it to be necessary (Table I).

Method.-Tube racks are designed to take 12 specimens per row ; it is convenient to have two-row racks, each row of which is given a reference letter (A, B, etc.) which is marked on the plate as shown in Plate III $a$. Using the appropriate pipette, rinsed out once with saline between specimens, one drop $(0.05 \mathrm{ml}$.) of each serum is placed in its respective circle, working from left to right, and starting with the outer six circles. The next row is pipetted on to the other half of the plate. Into each circle is now added one drop of antigen, which is mixed by inversion just before use. The motor of the "mixer" is wound up and the plate placed on the turntable, which is set going at the standard speed of 18 to 20 revolutions per minute for 10 minutes. This "standard speed" is empirical and is simply that which makes for smooth mixing of

\section{TABLE I}

RESULTS OBTAINED WITH 75 SERA BEFORE AND AFTER INACTIVATION

\begin{tabular}{|c|c|c|c|c|c|c|c|c|}
\hline & \multicolumn{8}{|c|}{ Modified Laughlen } \\
\hline & \multirow{2}{*}{ W.R. } & \multirow[b]{2}{*}{ Kahn } & \multicolumn{3}{|c|}{$\begin{array}{c}\text { Before } \\
\text { inactivation }\end{array}$} & \multicolumn{3}{|c|}{$\begin{array}{c}\text { After } \\
\text { inactivation }\end{array}$} \\
\hline & & & $\begin{array}{c}++ \\
+++ \\
\text { or } \\
++++\end{array}$ & + & - & $\begin{array}{c}++ \\
+++ \\
\text { or } \\
++++\end{array}$ & + & - \\
\hline 22 . & - & - & - & - & 22 & - & - & 22 \\
\hline 16 & - & ++ & 4 & 7 & 5 & 15 & 一 & $1^{*}$ \\
\hline 8 & \pm & ++ & - & 6 & 2 & 8 & - & 一 \\
\hline 4 & + & ++ & 1 & 2 & 1 & 4 & - & - \\
\hline 18 & ++ & ++ & 6 & 9 & 3 & 17 & $1^{*}$ & - \\
\hline 5 & ++ & +++ & 4 & 1 & - & 5 & - & - \\
\hline 2 & ++ & +++ & 2 & - & - & 2 & - & - \\
\hline 75 & (total) & & & & & & & \\
\hline
\end{tabular}

* Treated case. the contents of the circles without causing overflowing. (The speed control of the motor may need adjustment to obtain this slow rate.) The mixtures of antigen and serum should fill each circle and flow round smoothly inside the margins, but if any remains as a blob of liquid the motor should be stopped momentarily and with a piece of thin wire the fluid may be spread out gently to fill the circle's area. At the end of the 10 minutes the plate is removed from the turntable and the twenty-four tests examined by means of a $\times 6$ hand lens. The following results may be found:

Negative.-Appearance uniformly colloidal. No precipitate visible even with the lens.

Doubtful (+).-A very faint precipitate visible with the lens. Of no diagnostic importance.

Positive $(++)$. - A definite, fine precipitate, visible to the naked eye. Does not indicate syphilis per se, and requires confirmation by Wassermann and/or Kahn reactions.

Positive $(+++)$. - A heavy precipitate. Indicates syphilis in 95 per cent of cases.

Positive $(++++)$. - A very heavy precipitate, concentrated into roughly twelve "clumps," always indicates syphilis and is invariably accompanied by a ++ W.R. and a ++ , +++ , or ++++ Kahn.

The various degrees of positive precipitation are shown diagrammatically in Plate III $b$.

TABLE II

ANALYSIS OF 521 DISCREPANCIES OBTAINED WITH UNTREATED CASES

\begin{tabular}{|c|c|c|c|c|c|c|c|c|}
\hline \multicolumn{4}{|c|}{ Initial test } & \multicolumn{4}{|c|}{ Three weeks later } & \multirow{2}{*}{$\begin{array}{l}\text { No. of } \\
\text { sera } \\
\text { not } \\
\text { ob- } \\
\text { tained }\end{array}$} \\
\hline $\begin{array}{c}\text { No. } \\
\text { of } \\
\text { sera }\end{array}$ & W.R. & Kahn & M.L. & $\begin{array}{c}\text { No. } \\
\text { of } \\
\text { sera }\end{array}$ & W.R. & Kahn & M.L. & \\
\hline 260 & - & ++ & - & $\begin{array}{r}6 \\
203\end{array}$ & - & + & - & 51 \\
\hline 24 & \pm & - & - & 22 & - & - & - & 2 \\
\hline 155 & - & - & + & 64 & - & - & - & 91 \\
\hline 32 & - & - & ++ & $\begin{array}{r}3 \\
17 \\
8 \\
2\end{array}$ & $\begin{array}{c}++ \\
- \\
\pm\end{array}$ & $\begin{array}{c}++ \\
- \\
++\end{array}$ & $\begin{array}{c}+t+ \\
+ \\
++\end{array}$ & 2 \\
\hline 34 & \pm & + & ++ & $\begin{array}{l}2 \\
9\end{array}$ & $\begin{array}{c}++ \\
\pm\end{array}$ & $\begin{array}{c}+++ \\
+\end{array}$ & $\begin{array}{c}+++ \\
++\end{array}$ & 23 \\
\hline 16 & - & + & ++ & $\begin{array}{r}1 \\
12\end{array}$ & + & $+t$ & ++ & 3 \\
\hline 521 & (total & & & 349 & & & & 172 \\
\hline
\end{tabular}

M.L.-Modified Laughlen. 


\section{RESULTS}

The above modification of the Laughlen reaction has been tested with 16,824 sera, in parallel with the Wassermann (Wyler, 1929, 1931) and Kahn tests. Of these, 11,496 were diagnostic specimens and 5,328 from cases undergoing antisyphilitic treatment. In the former group, all three tests gave negative results with 374 , while 521 sera produced discordant results of one kind or another. These discrepancies have been analysed (Table II), and are discussed later. In the treated group, 1,460 specimens were positive with the three tests, and 2,448 negative. 1,420 sera gave discrepancies which are analysed in Table III.

\section{Discussion}

This modified Laughlen (M.L.) test is intended mainly for use as a quick and convenient screen test. To be useful, its sensitivity level must be such that no serum from a new, untreated case escapes detection, even though it may be classed as doubtful or weakly positive by other tests for syphilis. If the M.L. test is to be used for the control of treatment, its sensitivity must in every instance be at least as high as that of any standard test. Non-specific positives are to be expected in both instances, but, if comparatively few in number, they are of little importance because all positive sera should be re-tested by the Wassermann test, the Kahn test, or both.

Accordingly, the results of the investigation may be discussed in relation to untreated and treated cases.

TABLE III

DISCREPANT RESULTS WITH SERA FROM 1,420 TREATED CASES

\begin{tabular}{|c|c|c|c|}
\hline & W.R. & Kahn & M.L. \\
\hline 765 & - & - & ++ \\
\hline 582 & - & ++ & ++ \\
\hline 37 & - & ++ & - \\
\hline 6 & + & ++ & + \\
\hline 13 & \pm & ++ & - \\
\hline 17 & \pm & - & ++ \\
\hline $\begin{array}{r}1,420 \\
\text { (total) }\end{array}$ & & & \\
\hline
\end{tabular}

M.L.-Modified Laughlen.
Untreated cases.-No serum giving a positive Wassermann reaction was negative by the M.L. test. Direct agreement between the two methods was found in 10,975 tests, plus 260 (Table II), a total of 11,235 or 97.7 per cent. If the 121 cases in which re-testing produced agreement are added to this total the percentage rises to 98.5 , and it might be greater if more of the discrepant sera had been available for re-testing. In no instance was there any evidence of an earlier specific response to the Wassermann test than to the M.L. test, the 24 doubtful Wassermann results being accepted as non-specific on the evidence of the later tests. Of the 155 sera giving doubtful M.L. readings, all those available for re-testing were found negative, which confirms the belief that this degree of precipitation can usually be disregarded. Nevertheless it is a useful reaction to record, but does not imply that further examination of a serum is necessary unless this is indicated by suggestive clinical evidence.

A similar comparison with the Kahn test showed that no specific positive or "doubtful" result was ever found in a syphilitic serum giving a negative M.L. test. The large number, 260, of non-specific Kahn results in this series was due probably to the large number of sera from pregnant women. But if the doubtful M.L. results are disregarded substantial agreement was achieved with the Kahn test in 96 per cent of examinations, or in 98 per cent if the " three weeks later" results are taken into account.

Thus in a large series of serum examinations the M.L. test proved 100 per cent sensitive. Specificity in a screen test is of less moment. The number of non-specific positive MAL. results simply indicates the sera which have to be unnecessarily re-tested by Wassermann, Kahn, or both. In this series 82 positive M.L. reactions were associated with negative or doubtful Wassermann-Kahn results. Examination three weeks later showed that at least eight of such results were specific, therefore only 74 sera, approximately 0.7 per cent of the total, would have been re-tested unnecessarily by an accepted standard procedure had the M.L. test been used for screening. In one contingency, however, it may be desirable to know the actual non-specific rate of this test. If an immediate report is required-as, for instance, on a patient leaving the district, or on a blood donor prior to a direct transfusion-it may be helpful to know what reliance can be placed on this quick and convenient test. Its non-specific rate here was approximately 12 per cent. The Kline exclusion test has a non-specific rate of 9 per cent and the Hinton 


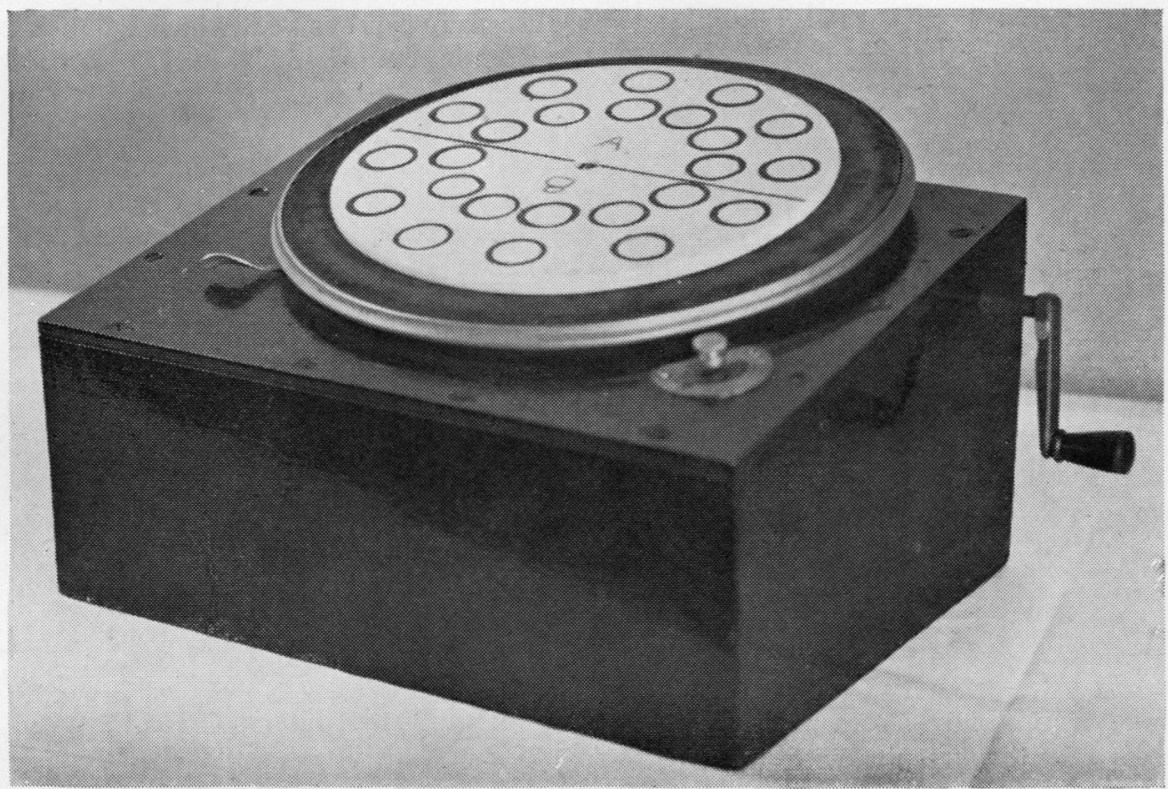

(a).-The mechanical mixer.

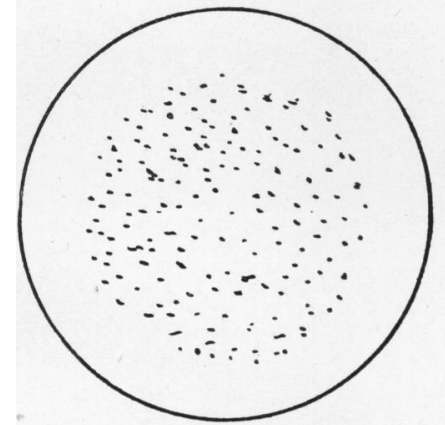

Positive $(++)$.

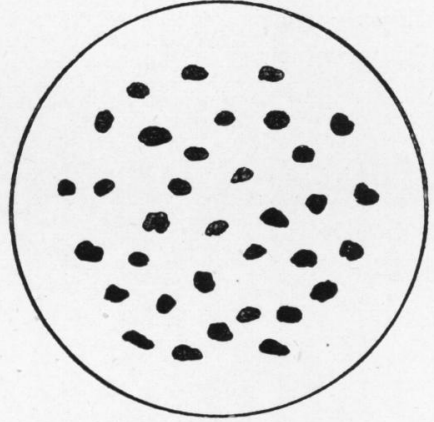

Positive $(+++)$.

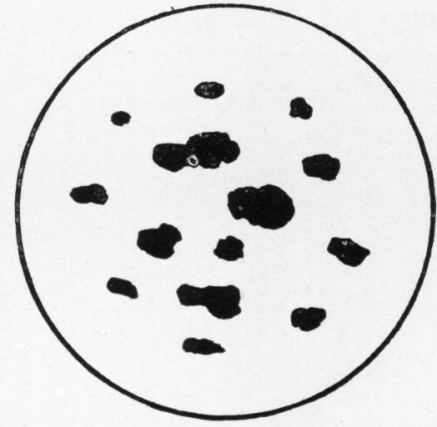

Positive $(++++)$.

(b) The various degrees of positive precipitation. All about $\times 2$ magnification.

Plate III 
and Kahn presumptive test approximately 5 per cent. But in this series the non-specific rate of the standard Kahn was unusually high at 10 per cent, so that the high rate of the M.L. was probably due more to the nature of the material examined than to any deficiency in the test. Nevertheless this finding supports the belief that complete sensitivity and specificity are not attainable in any one simple test. Should a report be required at short notice it is, however, permissible to use the M.L. test if only complete precipitation, the ++++ reading, be accepted as positive, and all intermediate grades of precipitation classed as doubtful. All positive and negative readings will then be entirely specific.

Treated cases.-Complete agreement with the Wassermann was recorded in approximately 73 per cent of the specimens examined, and this low rate of agreement between the two tests was due to the many instances where the M.L. remained positive after the Wassermann and Kahn had become negative (Table III). On the other hand, 13 sera which were positive in varying degrees with both Wassermann and Kahn, and 37 sera positive with Kahn only, gave negative results with the M.L. Although the Laughlen reaction usually remains positive after the Wassermann and Kahn have become negative, about 1 per cent of treated cases react negatively to the Laughlen while the other tests are still showing a positive result. This irregular sensitivity, and especially the poor correlation with the Kahn test, so widely applied to the control of antisyphilitic treatment, suggests that this version of the Laughlen test is unsuitable for use with treated cases.

\section{Summary}

The composition of the Laughlen antigen and the technique of performing the test have been investigated. From the findings a modified procedure has been evolved, which has been tested in the examination of 16,824 sera, 5,328 from treated cases, 11,496 from untreated cases. The findings suggest that the modified Laughlen test has no special merits as a final diagnostic test, that it is not suitable for the control of treated cases, but that it is especially valuable as a " screen " test for diagnostic specimens. The degree of sensitivity is such that no syphilitic serum is missed, yet com- $\dot{\omega}$ paratively few non-specific positives are encoun- $\vec{\sigma}$ tered. The antigen is easy to prepare by a $N$ standardized method and gives constant results for 을 at least four months from its date of manufacture. The whole test is extremely simple to perform.

I desire to express my thanks to Prof. W. J. Tulloch, $\overrightarrow{0}$ University College, Dundee, for his explanation of many points connected with the Laughlen reaction, and to Dr. R. D. Stuart, lately city bacteriologist, Glasgow, for his help and encouragement during this investigation. I should like also to acknowledge the assistance of many members of the staff of the Central Public Health Laboratory, Glasgow, without whose co-operation the investigation would not have been $\mathbb{D}$ possible.

\section{REFERENCES}

Hamilton-Paterson, J. L., Cole, W. T. S., and Usher, G. L. C. (1944) J. Path. Bact., 56, 335

Kahn, R. L. (1928). "The Kahn Test-a Practical Guide." Ballière Tindall, and Cox. London.

Kemp, R. (1939). Brit. J. vener. Dis., 15, 269.

Lane, C. R. (1944). Brit. J. vener. Dis., 20, 78.

Laughlen, G. F. (1935). Canad. med. Ass. J., 33, 179.

Laughlen, G. F. (1938). Canad. publ. Hlth J., 29, 396.

Laughlen, G. F. (1946). Brit. J. vener. Dis., 22, 15.

Lorenz, W. F. (1940). Amer. J. clin. Path., 10, 527.

Tulloch, w. J. Personal communication.

Wyler, E. J. (1929). Med. Res. Cncl Spec. Rep. Ser. No. 129. London.

Wyler, E. J. (1931). Report on Publ. Hith and med. Subjects. No. 음 67. London. 